University of Nebraska - Lincoln

DigitalCommons@University of Nebraska - Lincoln

Faculty Papers and Publications in Animal

Science

Animal Science Department

1962

\title{
Effect of Levels of Meat and Bone Scraps on Growth Rate and Feed Efficiency of Growing-Finishing Swine
}

\author{
E. R. Peo, Jr. \\ University of Nebraska-Lincoln \\ D. B. Hudman \\ Nebraska Agricultural Experiment Station
}

Follow this and additional works at: https://digitalcommons.unl.edu/animalscifacpub

Part of the Animal Sciences Commons

Peo, Jr., E. R. and Hudman, D. B., "Effect of Levels of Meat and Bone Scraps on Growth Rate and Feed Efficiency of Growing-Finishing Swine" (1962). Faculty Papers and Publications in Animal Science. 625. https://digitalcommons.unl.edu/animalscifacpub/625

This Article is brought to you for free and open access by the Animal Science Department at DigitalCommons@University of Nebraska - Lincoln. It has been accepted for inclusion in Faculty Papers and Publications in Animal Science by an authorized administrator of DigitalCommons@University of Nebraska - Lincoln. 


\title{
EFFECT OF LEVELS OF MEAT AND BONE SCRAPS ON GROWTH RATE AND FEED EFFICIENCY OF GROWING-FINISHING SWINE $^{1}$
}

\author{
E. R. Peo, JR. And D. B. Hudman \\ Nebraska Agricultural Experiment Station, ${ }^{2}$ Lincoln
}

\begin{abstract}
$\mathbf{M}$ ANY investigations have shown that soybean meal when properly supplemented can replace meat and bone scraps as a major source of protein in swine rations (Lepley et al., 1950; Terrill et al., 1954; Rohlf, 1954; Meade and Hanson, 1957; Meade et al., 1958; Becker et al., 1960). The importance of this finding is emphasized by the work of Bloss et al. (1953), Terrill et al. (1954), Meade and Teter (1957) and Becker and Jensen (1961) who reported a significant depression in growth rate and feed efficiency of swine fed rations containing relatively high levels of meat and bone scraps.

With livestock slaughter on the increase, it is apparent that meat and bone scraps, a by-product of the packing industry, will continue to be an available source of protein for swine. It was the purpose of these experiments to determine the relationship between level of meat and bone scraps in a ration and growth rate and feed efficiency of growingfinishing swine.
\end{abstract}

\section{Experimental}

Experiment 1. Seventy Yorkshire $\mathrm{x}$ Hampshire crossbred pigs, which averaged $36.5 \mathrm{lb}$. live weight, were allotted to two replications of five experimental treatments on the basis of breeding and weight outcome groups. The pigs were housed and fed in concrete-floor pens which were equipped with self-feeders and waterers.

Composition of the experimental rations is presented in table 1. A corn-soybean meal ration was used as the comparative basal ration. Meat and bone scraps (substituted for soybean meal in basal) were fed at levels of $2.5,5.0,7.5$ and $10 \%$ of the total ration. Since the ration formulated with $10 \%$ meat and bone scraps calculated $1.0 \%$ calcium and

1 Published with the approval of the Director as paper No. 1246, Journal Series, Nebraska Agricultural Experiment Station. 2 Department of Animal Husbandry. Acknowledgement is made to $P$. F. Cunningham and associates for assistance in caring for the experimental animals and to Chas. Pfizer and Co., Inc. Terre Haute, Indiana and Merck and Co., Inc., Rahway, New Jersey for certain of the experimental ingredients.
$0.70 \%$ phosphorus, all rations were adjusted to these levels for calcium and phosphorus. One commercial source of meat and bone scraps was used in this experiment. The rations were fed in meal-form and the experiment was terminated after 84 days.

Experiment 2. Seventy Yorkshire x Hampshire $x$ Landrace cross-bred pigs which averaged $43.0 \mathrm{lb}$. live weight were allotted on the basis of weight outcome groups to two replications of five experimental treatments. Housing and management were essentially the same as previously described for the first experiment. The experimental rations fed were also the same (see table 1) except that a blend of four commercial sources of meat and bone scraps was used. In addition, a calcium-phosphorus ratio of approximately $1.42: 1$ was maintained in all rations. The ratio was determined by the levels of calcium and phosphorus $(0.57 \%$ and $0.40 \%$, respectively) in the corn-soybean meal basal ration. The experiment was terminated after 98 days.

Experiment 3. One hundred and eight Hampshire $\mathrm{x}$ Yorkshire crossbred pigs which averaged $37.0 \mathrm{lb}$. live weight were allotted by weight outcome groups to three replications of a $2 \times 3$ factorial experiment in which a flavoring compound and levels of meat and bone scraps were the dietary variables. As shown in table 1 , the corn-soybean meal basal and the 5 and $10 \%$ meat and bone scraps rations were fed with and without $0.025 \%$ of a flavoring compound (trade name--SucroFlavor; see table 1 for composition). This compound was used in an attempt to equalize all rations in respect to flavor and possibly palatability since the results of the first two experiments had indicated a reduction in average daily feed intake when the ration contained $10 \%$ meat and bone scraps. Housing and management were the same as described previously. The experiment was terminated after 84 days.

In all three experiments, pig weights and feed data were collected at two-week intervals. The pen-of-pigs was used as the experi- 
TABLE 1. COMPOSITION OF EXPERIMENTAL RATIONS

\begin{tabular}{|c|c|c|c|c|c|c|c|c|c|c|}
\hline \multirow[b]{2}{*}{ Ration designation ${ }^{\mathrm{d}}$} & \multirow[b]{2}{*}{$\mathrm{C}-\mathrm{SB}$} & \multicolumn{4}{|c|}{ Experiment $1^{a}$} & \multirow[b]{2}{*}{$\mathrm{C}-\mathrm{SB}$} & \multicolumn{4}{|c|}{ Experiments 2 and $3^{b+c}$} \\
\hline & & $\begin{array}{l}2.5 \% \\
\text { MBS }\end{array}$ & $\begin{array}{l}5 \% \\
\text { MBS }\end{array}$ & $\begin{array}{l}7.5 \% \\
\text { MBS }\end{array}$ & $\begin{array}{l}10 \% \\
\text { MBS }\end{array}$ & & $\begin{array}{l}2.5 \% \\
\text { MBS }\end{array}$ & $\begin{array}{l}5 \% \\
\text { MBS }\end{array}$ & $\begin{array}{l}7.5 \% \\
\text { MBS }\end{array}$ & $\begin{array}{l}10 \% \\
\text { MBS }\end{array}$ \\
\hline \multicolumn{11}{|l|}{ Ingredients, lb. } \\
\hline Ground yellow corn & 80.4 & 81.5 & 82.5 & 83.5 & 84.4 & 82.5 & 83.4 & 83.7 & 84.1 & 84.3 \\
\hline $50 \%$ soybean meal & 14.7 & 12.0 & 9.3 & 6.7 & 4.0 & 14.3 & 11.7 & 9.1 & 6.5 & 4.0 \\
\hline $50 \%$ meat and bone scraps ${ }^{\circ}$ & $\ldots$ & 2.5 & 5.0 & 7.5 & 10.0 & $\ldots$ & 2.5 & 5.0 & 7.5 & 10.0 \\
\hline Salt (iodized) & 0.5 & 0.5 & 0.5 & 0.5 & 0.5 & 0.5 & 0.5 & 0.5 & 0.5 & 0.5 \\
\hline Dicalcium phosphate & 2.3 & 1.7 & 1.1 & 0.4 & $\ldots$ & 0.6 & $\ldots$ & $\ldots$ & $\ldots$ & $\ldots$ \\
\hline Ground limestone & 1.0 & 0.7 & 0.5 & 0.3 & $\ldots$ & 1.0 & 0.8 & 0.6 & 0.3 & 0.1 \\
\hline Trace minerals ${ }^{x}$ & 0.1 & 0.1 & 0.1 & 0.1 & $\ddot{0.1}$ & 0.1 & 0.1 & 0.1 & 0.1 & 0.1 \\
\hline Vitamin-antibiotic premix & 1.0 & 1.0 & 1.0 & 1.0 & 1.0 & 1.0 & 1.0 & 1.0 & 1.0 & 1.0 \\
\hline
\end{tabular}

a Calculated content of protein, $14 \%$; calcium, $1.0 \%$; phosphrous, $0.70 \%$.

b Calculated content of protein, $14 \%$; calcium and phosphorus could not be maintained at the levels present in the corn-soy basal $(0.57$ and 0.40 , respectively) with high levels of meat and bone scraps. However, the calcium-phosphorus ratio was held at approximately $1.42: 1$.

c For Experiment 3, C-SB, 5\% and $10 \% \mathrm{MBS}$ rations were fed with and without $0.025 \%$ of a flavoring compound (trade name, Sucro-Flavor). Generai composition of the compound was sodium saccharin, sodium cyclamate, vanillin and other alde hydes, anethole, ethyl lactate and other esters, oil orange and other essential oils, citric acid and other organic acids, diacetyl and other ketones, vegetable gum and sugar. Exact composition unknown to authors. Sucro-Flavor is a product of Flavor Corporation of America, Chicago. U. S. Patent No. 2,932,571.

d C-SB-corn-soybean meal basal; MBS-meat and bone scraps.

- One source in Experiment 1 ; blend of 4 sources in Experiments 2 and 3

Calcium Carbonate Company, standard swine mix ( $5 \%$ zinc).

Contributed the following amounts of vitamins and antibiotics per pound of complete ration: vit, A, $1200 \mathrm{I} U$. vit $D$ 180 I.U.; riboflavin, $1.0 \mathrm{mg}$; niacin, $4.5 \mathrm{mg}$; calcium pantothenate, $2.0 \mathrm{mg}$; choline chloride, $105 \mathrm{mg}$-; vit. B12, $5.0 \mathrm{mcg}$.; oxytetracycline, $10 \mathrm{mg}$.

mental unit and the data were analyzed according to analysis of variance methods. All statements concerning statistical significance are for $\mathrm{P}<.05$.

\section{Results}

Experiment 1. The results of this experiment are presented in table 2. The greatest average daily gains were made by pigs fed the corn-soybean meal basal (C-SB) and the $2.5 \%$ meat and bone scraps (MBS) rations. Pigs fed the rations containing 10\% MBS gained from 0.10 to $0.16 \mathrm{lb}$. less per day than those fed the other treatments. The linear regression of average daily gain on levels of meat and bone scraps was significant.

There were no significant differences among

TABLE 2. EFFECT OF LEVELS OF MEAT AND BONE SCRAPS ON GROWTH RATE AND FEED CONVERSION OF SWINE ${ }^{\text {a }}$ (EXPERIMENT 1)

\begin{tabular}{lccccc}
\hline & & & & & \\
Ration designation & $\mathrm{C}-\mathrm{SB}$ & $\begin{array}{c}2.5 \% \\
\text { MBS }\end{array}$ & $\begin{array}{c}5.0 \% \\
\text { MBS }\end{array}$ & $\begin{array}{c}7.5 \% \\
\text { MBS }\end{array}$ & $\begin{array}{c}10.0 \% \\
\text { MBS }\end{array}$ \\
\hline $\begin{array}{lcccc}\text { Pens per treatment, no. } \\
\text { Pigs per pen, no. }\end{array}$ & 2 & 2 & 2 & 2 & 2 \\
Av. initial wt., lb. & 36.5 & 36.5 & 36.5 & 39.2 & 39.3 \\
Av. daily gain, lb.c, d & 1.54 & 1.56 & 1.50 & 1.52 & 1.40 \\
Av daily feed & & & & & \\
$\quad$ intake, lb.d & 4.71 & 4.77 & 4.65 & 4.97 & 4.56 \\
Feed per lb. gain, lb.d & 3.06 & 3.06 & 3.10 & 3.27 & 3.26
\end{tabular}

a Duration of test, 84 days.

b One pig removed during test.

c Linear regression of average daily gain on levels of meat and bone scraps significant $(\mathrm{P}<.05)$

d Error mean squares for gain, feed intake and feed/lb. gain are $0.0024,0.0097$ and 0.0162 , respectively. treatments in average daily feed intake or feed required per pound of gain. However, less feed was required per pound of gain (0.04 to $0.21 \mathrm{lb}$.) with C-SB and $2.5 \%$ MBS than was used with rations containing 5.0, 7.5 and $10 \%$ MBS.

Experiment 2. As shown in table 3, the greatest gains were made by pigs fed the $\mathrm{C}-\mathrm{SB}$ and the $2.5 \% \mathrm{MBS}$ rations as was observed in the first experiment. Gains tended to decrease as the level of MBS was increased in the ration. The decrease resulted in a significant linear regression of average daily: gains on levels of MBS.

Average daily feed intake of pigs fed the $\mathrm{C}-\mathrm{SB}$ and the $2.5 \%$ MBS ration was 1.05 and $1.16 \mathrm{lb}$. more, respectively, than that of pigs fed the $10 \%$ MBS ration. The linear regression of average daily feed intake on levels of MBS was significant.

There were no significant differences among treatments in feed required per pound of gain. However, the pigs fed the C-SB used less feed per pound of gain (0.08 to $0.12 \mathrm{lb}$.) than those fed rations containing meat and bone scraps.

Experiment 3. The results of this experiment are presented in table 4 . On the average, pigs fed the C-SB ration gained 0.04 and $0.24 \mathrm{lb}$. more per day than those fed 5 and $10 \%$ MBS, respectively. Differences were less when the ration contained $0.025 \%$ SucroFlavor. The linear regression of average daily 
TABLE 3. EFFECT OF LEVELS OF MEAT AND BONE SCRAPS ON GROWTH RATE AND FEED CONVERSION OF SWINE ${ }^{\text {a }}$

(EXPERIMENT 2)

\begin{tabular}{lccccc}
\hline \hline Ration designation & C-SB & $\begin{array}{c}2.5 \% \\
\text { MBS }\end{array}$ & $\begin{array}{c}5.0 \% \\
\text { MBS }\end{array}$ & $\begin{array}{c}7.5 \% \\
\text { MBS }\end{array}$ & $\begin{array}{c}10.0 \% \\
\text { MBS }\end{array}$ \\
\hline Pens per treatment, no. & 2 & 2 & 2 & 2 & 2 \\
Pigs per pen, no. & 7 & 7 & 7 & 7 & 7 \\
Av. initial wt., lb. & 43.1 & 43.0 & 42.9 & 43.0 & 43.1 \\
Av, daily gain, lb. b, c & 1.63 & 1.61 & 1.44 & 1.44 & 1.26 \\
Av. daily feed & & & & & \\
$\quad$ intake, lb. b & 5.34 & 5.45 & 4.85 & 4.85 & 4.29 \\
Feed per lb. gain, lb. c & 3.28 & 3.37 & 3.36 & 3.36 & 3.40 \\
\hline
\end{tabular}

a Duration of test, 98 days.

b Linear regression of average daily gain and feed intake on levels of meat and bone scraps significant. $(\mathrm{P}<.05)$.

c Error mean squares for gain, feed intake and feed/lb. gain are $0.0038,0.0329$ and 0.0044 , respectively.

gains on levels of MBS was significant. Differences between flavored and unflavored diets were not significant.

The linear regressions of average daily feed intake and feed required per pound of gain on levels of MBS were significant. The addition of flavor to rations formulated with MBS did not result in a significant change in average daily feed intake and feed conversion. None of the interactions were significant.

\section{Discussion}

In all three experiments, growth rate was depressed significantly when pigs were fed a ration containing $10 \% \mathrm{MBS}$. In experiment 1 , all ration treatments were equalized for calcium and phosphorus at levels of 1.0 and $0.70 \%$ of the total ration, respectively. Thus, the growth depressing effect of MBS does not appear to be due to a high mineral level. This contention is supported also by the work of Becker and Jensen (1961) who observed that growth rate of swine was not affected by calcium levels as high as 0.90 to $0.95 \%$ of the ration in a corn-soybean meal and meat and bone scraps ration.

In experiments 2 and 3 , the calcium and phosphorus levels in the C-SB were 0.57 and $0.40 \%$, respectively. The level of these two minerals unavoidably increased in the rations formulated with 5.0, 7.5 and $10 \% \mathrm{MBS}$ because of the relatively high percent of calcium and phosphorus in meat and bone scraps. Since ratio appears to be more critical than amount (Combs et al., 1962; Chapman et al., 1962) the calcium-phosphorus ratio was held constant in all diets at approximately 1.42:1. Under these experimental conditions, it appears that growth rate and feed intake were more severely depressed than was observed in experiment 1 .
Rohlf (1954) reported a large variation in quality, uniformity and extent of putrefaction in meat and bone scraps. If putrefaction contributes to variations in taste, smell or palata. bility of rations formulated with MBS, the addition of a flavoring compound such as used in experiment 3 may prove beneficial since gains, feed intake and feed efficiency were improved when a flavor was added to the diets containing MBS.

It is also possible that rations formulated with MBS may be unbalanced with respect to essential amino acids. This may have been the primary cause for the depression in growth rate, feed intake and feed efficiency of swine in these experiments. Bloss et al. (1953) suggested that MBS does not contain sufficient tryptophan for optimum growth. However, these workers fed diets containing $20 \%$ MBS which was twice the maximum level fed in the experiments described herein. The effect of amino acid supplementation of rations formulated with MBS will be reported in a subsequent paper.

\section{Summary}

Three experiments were conducted with 248 crossbred pigs to determine the effects of level of meat and bone scraps in the ration (2.5 to $10 \%$ ) on gains and feed efficiency of growingfinishing swine. In all three experiments the negative linear regression of average daily

TABLE 4. EFFECT OF LEVELS AND FLAVOR OF MEAT AND BONE SCRAPS ON GROWTH RATE AND FEED CONVERSION OF SWINE ${ }^{a, b}$ (EXPERIMENT 3)

\begin{tabular}{|c|c|c|c|}
\hline \multirow{2}{*}{$\begin{array}{l}\text { Level of } \\
\text { meat and } \\
\text { bone scraps }\end{array}$} & \multicolumn{2}{|c|}{ Flavor } & \multirow{2}{*}{$\begin{array}{r}\text { Av, of level } \\
\text { of meat and } \\
\text { bone scraps }\end{array}$} \\
\hline & Without & With & \\
\hline$\%$ & \multicolumn{2}{|c|}{ Av. daily gain (lb.) } & \\
\hline $\begin{array}{r}0 \\
5 \\
10\end{array}$ & $\begin{array}{l}1.61 \\
1.51 \\
1.32\end{array}$ & $\begin{array}{l}1.60 \\
1.62 \\
1.39\end{array}$ & $\begin{array}{l}1.60 \\
1.56 \\
1.36\end{array}$ \\
\hline \multirow[t]{2}{*}{ Av. of flavor } & 1.48 & 1.54 & $\ldots$ \\
\hline & \multicolumn{2}{|c|}{ Av. daily feed intake (lb. } & \\
\hline $\begin{array}{r}0 \\
5 \\
10\end{array}$ & $\begin{array}{l}5.16 \\
4.98 \\
4.44\end{array}$ & $\begin{array}{l}5.16 \\
5.30 \\
4.60\end{array}$ & $\begin{array}{l}5.16 \\
5.14 \\
4.52\end{array}$ \\
\hline \multirow[t]{2}{*}{ Av. of flavor } & 4.86 & 5.02 & $\ldots$ \\
\hline & \multicolumn{2}{|c|}{ Av. feed/lb, gain (lb.) } & \\
\hline $\begin{array}{r}0 \\
\mathbf{5} \\
10\end{array}$ & $\begin{array}{l}3.20 \\
3.28 \\
3.36\end{array}$ & $\begin{array}{l}3.21 \\
3.27 \\
3.28\end{array}$ & $\begin{array}{l}3.20 \\
3.28 \\
3.32\end{array}$ \\
\hline Av. of flavor & 3.28 & 3.25 & $\ldots$ \\
\hline
\end{tabular}

a Duration of test, 84 days.

a Values are average of 18 pigs per treatment; av. intial wt. $37 \mathrm{lbs}$.

cinear regression of average daily gain, feed intake and feed/lb. gain on levels of meat and bone scraps significant $(\mathrm{P}<.05)$.

d Error means squares for average daily gain, feed intake and feed/lb. gain are $0.0225,0.1990$ and 0.0052 , respectively. 
gains on levels of meat and bone scraps was significant. The addition of $0.025 \%$ SucroFlavor to rations containing meat and bone scraps resulted in greater gains but the increase was not significant.

In experiments 2 and 3 , feed intake decreased with increasing levels of meat and bone scraps. The linear regression of feed intake on levels of meat and bone scraps was significant. In general, feed required per pound of gain was not appreciably affected by level of meat and bone scraps.

\section{Literature Cited}

Becker, D. E. and A. H. Jensen. 1961. The effects of levels of calcium upon the rate and efficiency of gain in growing-finishing swine. Univ. IIl. AS-556.

Becker, D. E., A. H. Jensen and S. W. Terrill. 1960. Supplementation of rations for growing swine. Univ. Ill. AS-534.

Bloss, R. E., R. W. Luecke, J. A. Hoefer, F. Thorp, Jr. and W. N. McMillen. 1953. Supplementation of a corn-meat and bone scraps ration for weanling pigs. J. Animal Sci. 12:102.

Chapman, H. L., Jr., J. Kastelic, G. C. Ashton, P. G.
Homeyer, C. Y. Roberts, D. V. Catron, V. W. Hays and V. C. Speer. 1962. Calcium and phosphorus requirements of growing-finishing swine. J. Animal Sci. $21: 112$.

Combs, G. E., J. M. Vandepopuliere, H. D. Wallace and M. Kroger. 1962. Phosphorus requirement of young pigs. J. Animal Sci. $21: 3$.

Lepley, K. C., D. V. Catron and C. C. Culbertson. 1950. Dried whole aureomycin mash and meat and bone scraps for growing-fattening swine. J. Animal Sci. 9:608.

Meade, R. J. and L. E. Hanson. 1957. The influence of source of dietary protein upon performance of pigs fed in drylot. Minn. Agr. Exp. Sta. Rpt. H-128.

Meade, R. J., L. E. Hanson and R. M. Prouty. 1958. Further attempts to improve a corn-soybean oil meal type ration for growing-finishing swine. Minn. Agr. Exp. Sta. Rpt. H-159.

Meade, R. J. and W. S. Teter. 1957. The influence of calcium pantothenate, tryptophan and methionine supplementation, and source of protein upon performance of growing swine fed corn-meat and bone scraps rations. J. Animal Sci. 16:892.

Rohlf, M. E. 1954. Variability of commercially produced meat and bone scraps. M.S. Thesis. Iowa State University, Ames, Iowa.

Terrill, S. W., D. E. Becker, H. W. Norton, W. K. Warden and C. R. Adams. 1954. Some plant and animal sources of crude protein for weanling pigs fed in drylot. J. Animal Sci. 13:622. 